\title{
EFFECT OF COMPOST AND POTASSIUM PHOSPHATE APPLICATIONS TO A CALCAREOUS SOIL CULTIVATED WITH VEGETABLE CROPS ROTATION ON THEIR PRODUCTION AND SOIL FERTILITY \\ Hassanein, A. H. A.; A. M. M. Abdel-Fattah; Kadria M. El-Azab and A. H. Abd - Elrahman \\ Soil, Water and Environment Res. Institute, Agric. Res. Centre, Giza, Egypt
}

\begin{abstract}
A field experiment was carried out on a calcareous soil at Abou massou village (48 km south-west to Alexandria) with four vegetable crops cultivated in succession (garlic, , cauliflower and jews mallow) was conducted to investigate how application rates of plants residues trim farm operations compost and potassium phosphate, also, the vegetable dry matter \& their NPK uptake can affect the yield. The study also investigated the resultant effects on soil fertility. Irrigation was up to field capacity using canal water.

Results indicated that soil salinity, soluble chlorides and sodium decreased sharply after garlic and gradually after that, while bicarbonates increased sharply during the first months and decreased gradually at a level higher than the start point. Sulphates, calcium, magnesium and potassium decreased over the time. Rates of compost application were without pronounced effect on total soluble salts or soluble cations and anions with the exception of bicarbonates.

Rates of plants residues trim farm operations compost and potassium phosphate included also vegetable dry matter and their NPK uptake in addition to soil properties and vegetable yields through 20 -months were also studied.

Results indicate that each of the use compost rates were effective in increasing dry matter, $\mathrm{N}$ and $\mathrm{P}$ uptake by the three vegetable crops over the control. The same trend was noticed also at the phosphate and potassium treatments. It may be concluded that vegetable crop production in calcareous soil depend on the direct and residual effect of organic and mineral $\mathrm{N}$ and $\mathrm{P}$ fertilization for 20 months period and $\mathrm{K}$ fertilization for about three quarters of this period.

Also, the compost application might improve the soil properties while the addition of phosphorus and potassium enhances the availability of nutrients in the soil throughout the cropping period.

Key words: Calcareous soil, plants residues trim farm operations compost, Phosphorous, Potassium and Vegetable crops.
\end{abstract}

\section{INTRODUCTION}

Soils under intensive production are commonly subject to fertility syndromes as a result of nutrients deficiency which leads in turn to a marked decline in its productivity. Addition of fertilizers and soil amendments improve productivity levels and conserves the soil to a greater extent. Weak and poor soils might require special attention and interventions. Abdel-Hady et al (2000).

Composts at high quality ready organic manures were suggested for long time ago and still under investigation. Kaddous and Morgans (1986) studied the effect of spent mushroom compost and deep litter fowl manure as a soil amendment for vegetables in sandy loam soil. They noticed that soil 
thermal conductance and bulk density decreased and its water-stable aggregates $(>0.25 \mathrm{~mm})$, hydraulic conductivity, water retention, $N, P, K$ and organic $C$ increased with increasing rates of applications without increases in soil salinity to the harmful level. Kanwar et al (2002) used 25 ton/ha vermicomposting to low fertile soil planted with cauliflower resulted in a marked increase in the soil organic content when organic fertilizers were added alone compared to NPK fertilizers alone. Negm et al (2003) applied 4 ton/fed compost to calcareous soil at Noubaria cultivated with squash and table-beets. They found after 10 months of application slight increase in W.H.C. and T.S.S. due to increases in $\mathrm{HCO}_{3}, \mathrm{Cl}$ and $\mathrm{Na}$. Soil $\mathrm{pH}$ was reduced just after addition and in a small range by the advance of time. CEC increased and decreased by time. Meanwhile, NPK in soil increased after compost application and reduced gradually by time. It was also found that the $\mathrm{OM}$, total $\mathrm{N}$ content counts of total and cellulose decomposer bacteria and dehydrogenase activity increased after the compost application where the curve was at its peak after squash and gradually reduced.

Concerning $P$ and $K$ status in such calcareous soil, Abd-El-Hadi et al (2000) reported that fertility status in terms of the available soil NPK content was improved by increasing the fertilizer levels. Under proposed crop rotation with intensive cropping patterns, soil contents of $N, P$ and $K$ increased due to the higher amounts of the applied $N, P$ and $K$ fertilizers. Potassium phosphate was suggested as a soluble phosphate form by Mengel and Kirkby (1979), Oosterhuis (1997) and Hamdia et al (2000) as soil or foliar application to multi cut vegetables and maize, respectively. The latter was under salt stress.

Khalaf and Taha (1988), Sono et al (1994), Mohammad and Zuraiqi (2003) and Naik and Hosamani (2003), respectively recommended in case of garlic, the application of $50 \mathrm{~m}^{3} /$ ha of organic manure, 30 ton/ha of compost, 120 and $150 \mathrm{~kg} / \mathrm{ha}$ of mineral $N$ were found to be better than other treatments. Phosphorus application rate was also recommended for garlic by 450 and $75 \mathrm{~kg} \mathrm{P} \mathrm{O}_{5} / \mathrm{ha}$ according to Sono et al. (1994) and Naidu et al. (2000), respectively. Naidu et al. (2000) and Nagoich et al (2003) gave a rate of 50 and $120 \mathrm{~kg} \mathrm{~K} 2 \mathrm{O} / \mathrm{ha}$, respectively as the best rate for garlic. In spite of its leguminous nature, Cowpea was classified as $\mathrm{N}$ fertilization requiring crop as noted by Selvi et al (2002), Lehmann et al (2003), Oliveira et al (2003) and Patidar et al (2003),

For Cauliflower, Jakse and Mihelic (2001) using FYM and three different composts one of them was consisted of shredded wood and barks, Kumar and Choudhary (2002) comparing 25 ton/ha FYM with 100\% recommended NPK and both of them. On the other hand, Mishra (1992), Gupta et al (2002) and Jana and Mukhopadhyay (2002) found that 150, 200 and $100 \mathrm{~kg}$ mineral $\mathrm{N} / \mathrm{ha}$, respectively were the best under the experiment condition of each. The latter reference recommend $120 \mathrm{~kg} \mathrm{P}_{2} \mathrm{O}_{5} / \mathrm{ha}$ for high quality seed yield. Kanwar et al. (2002) and Jim (2002) investigated the effect of complete or half-recommended doses of NPK to minimize the mineral fertilizer applications.

Tindall (1983) and Rubatzky and Yamagucbi (1999) reported that Jews mallow is an intensive and densely growing plant requiring the application of 
complete fertilizers dose before sowing additional surface dressings of $\mathrm{N}$ fertilizer may be required to stimulate leaf production once plants are well established.

From all these literatures, vegetable crops are considered as good test plants to study the effect of fertilizers and soil amendments on increasing crop productivity. The target of the current work was to study the effect of the suggested The compost in combination with rates and forms of phosphorus and potassium fertilizers on high consumption plants has be recommended for calcareous soils.

\section{MATERIALS AND METHODS}

\section{Compost preparation:}

Four ton plants residues trim farm operations chopped, $8 \mathrm{~m}^{3}$ fresh cattle dung, $200 \mathrm{~kg}$ ammonium sulphate and $200 \mathrm{~kg}$ calcium super phosphate was composted as suggested by Bertron and Andreas (1994) for four months where the final analyses of that compost was shown in Table (1) following the methods described by Brummer and Wasmer (1978).

Soil

A field experiment was carried out during the seasons of 2013/2014 on a calcareous soil at Abou Masooud farm (48 Km south-west to Alexandria) Alexandria Governorate, Egypt. Some physical and chemical properties of the studied soil are presented in Table (2) analyzed according to Black et al. (1965).

\section{Studied crops}

Seeds of Garlic (Allium sativum, L.), cowpea (Vigna sinensis Savi.), cauliflower (Brassica oleracea var. botrytis $L$.) and jews mallow (Corchorus olitorius, L.). Seeds were sown in plots $(3 \times 3.5 \mathrm{~m})$ area. Before sowing the plots were settled.

\section{Experimental plots}

The experiment was designed in a split-split plot design with four replicates. The treatments included the following:

\section{The main treatments:}

1) Three levels of compost fertilizers, i.e. O, $2.5 \%$ and $5 \%$ (of the $15 \mathrm{~cm}$ depth plot soil weight) control treatment.

\section{Sub- main treatment:}

1) $\mathrm{K}_{2} \mathrm{SO}_{4}$ applied at a rate of $40 \mathrm{~kg} \mathrm{~K} / \mathrm{fed}$ and $18 \mathrm{~kg} \mathrm{~S} / \mathrm{fed}$.

2)Adding the double rate of the previous treatment $(80 \mathrm{~kg} \mathrm{~K} / \mathrm{fed}$. and $36 \mathrm{~kg} \mathrm{~S} /$ fed.).

3)Add monohydrogen dipotassium phosphate $\left(\mathrm{HK}_{2} \mathrm{PO}_{4}\right)$ with rate $40 \mathrm{~kg} \mathrm{~K} / \mathrm{fed}$ corresponding $8 \mathrm{~kg} P / \mathrm{fed}$.

4) The double dose of $\mathrm{HK}_{2} \mathrm{PO}_{4}$ was applied corresponding (80 kg K/fed and $16 \mathrm{~kg} P / \mathrm{fed})$

5)From each compost treatments were left without any $P$ or $K$ application as a control. 


\section{Field experiment conduct:}

The lobes of garlic (Allium sativum, L.) were sown on the $1^{\text {st }}$ of October 2012 plots. One third of plots were mixed with 5\% plant farm compost, another one third mixed with $2.5 \%$ plant farm compost and the rest plots was left without compost as a control. On the $21^{\text {th }}$ of October and $12^{\text {th }}$ of November 2012 plots were received two equal doses of phosphorus potassium fertilization according to the following arrangement. (A) 12 plots (4 ones from each compost treatment) were left without any $P$ or $K$ application as a control, (B) 12 plots received in each dose corresponding $40 \mathrm{~kg} \mathrm{~K} / \mathrm{fed}$. and $18 \mathrm{~kg} \mathrm{~S} / \mathrm{fed}$. (C) 12 plots received to the double rate $80 \mathrm{~kg} \mathrm{~K} / \mathrm{fed}$. and 36 $\mathrm{kg} \mathrm{S} / \mathrm{fed}$. (D) 12 plots received the rate $40 \mathrm{~kg} \mathrm{K/fed} \mathrm{in} \mathrm{the} \mathrm{form} \mathrm{of}$ monohydrogen dipotassium phosphate $\left(\mathrm{HK}_{2} \mathrm{PO}_{4}\right)$ corresponding $8 \mathrm{~kg} P / f e d$ and (E) 12 plots received the double dose of $H_{2} \mathrm{PO}_{4}$. Irrigation was stopped at $18^{\text {th }}$ of February 2013 where garlic was harvested on the $1^{\text {th }}$ of March 2013.

Soil samples were collected from each plot for analyses. The plots were clearing then the soil of every four replicate plots was settled and seeds of cowpea (Vigna sinensis Savi.) were sown on the $7^{\text {th }}$ of March 2013. After two weeks from planting seedlings were thinned to stand two plants ones only per hill. Irrigation was done four times up to plant maturity. Plants of each plot were harvested on the $12^{\text {th }}$ of August 2013 where each plant was divided into seeds and straw.

The same technique of soil sample taking and four replicates was followed then the filed clearing therefore the soil of every four replicate plots was settled and 2 seedlings (30-day age) of cauliflower (Brassica oleracea var. botrytis L.) were transplanted in each plot on $10^{\text {th }}$ of September 2013. After three weeks one plant only stayed in each hill. On the $10^{\text {th }}$ of October and $5^{\text {th }}$ of November 2013, the same programme of $P$ and $K$ fertilization was followed in the same plots. The plants were irrigated when they need, after 150 days from planting ( $11^{\text {th }}$ of February 2014) plants was cut, where soil sample was collected from each plot for analyses.

The filed clearing then the soil of every four replicate plots was settled, where seeds of jews mallow (Corchorus olitorius, L.) were planted on the $17^{\text {st }}$ of March 2014. Plants were left without thinning and only treated, its where irrigation when they need. Plant cutting was on the 1st of June 2014 where soil sample was taken from each plot.

Total soluble salts by estimating soil electrical conductivity $(E C)$, soluble anions, cations, cation exchange capacity (CEC), organic matter (O.M.), were determined by the methods described by Black et al (1965). Total $N$ contents, available $P$ and $K$ in soil were determined according to Jackson (1973).

After cutting of each vegetable, plants were $75{ }^{\circ} \mathrm{C}$ oven dried, ground and wet digested by the method described by Sommers and Nelson (1972) and their contents of $N, P$ and $K$ were determined according to Chapman and Pratt (1961) Available N, P and K in soil were determined according to Jackson (1973).. Data were statistically analyzed according to Petersen (1976). 
Tables 1 and 2 showed the compost and soil analyses according to Brummer and Wasmer (1978) for compost and Black et al (1965) for soil.

\begin{tabular}{|l|c|l|c|}
\hline \multicolumn{1}{|c|}{ Table (1): Characterizing analyses of the prepared compost. } \\
\hline Determination & Value & Determination & Value \\
\hline Colour & Redden brown & Organic matter \% & 59.13 \\
\hline Moisture \% & 39.70 & Organic carbon \% & 34.29 \\
\hline Water holding capacity \% & 110.00 & Total N \% & 1.02 \\
\hline Total soluble salts \% & 0.51 & Total P \% & 0.35 \\
\hline pH (1:10 water suspen.) & 7.10 & Total K \% & 0.63 \\
\hline CEC (me/100g compost) & 68.24 & C/N ratio & 33.62 \\
\hline
\end{tabular}

Table (2): Some physical and chemical properties of the soil under investigation.

\begin{tabular}{|c|c|c|c|}
\hline \multicolumn{2}{|c|}{$\begin{array}{l}\text { Practical size distribution in presence of } \\
\mathrm{CaCO}_{3}\end{array}$} & \multirow[b]{2}{*}{$\mathrm{EC}(\mathrm{dS} / \mathrm{m})$} & \multirow[b]{2}{*}{12.36} \\
\hline Clay $\quad(\%)$ & 15.20 & & \\
\hline$(\%)$ & 20.70 & Cations meq/L & \\
\hline Fine sand & 43.20 & $C a^{2+}$ & 44.88 \\
\hline Coarse sand & 20.90 & $M g^{2+}$ & 21.85 \\
\hline Textural class: Sandy clay & & $\mathrm{Na}^{+}$ & 92.40 \\
\hline $\mathrm{CaCO}_{3} \quad(\%)$ & 33.40 & $K^{+}$ & 3.73 \\
\hline O.M. & 1.09 & Anions $\mathrm{meq} / \mathrm{L}$ : & \\
\hline$(\%)$ & 0.53 & $\mathrm{CO}_{3}^{2-}$ & Nil \\
\hline W.H.C. & 42.60 & $\mathrm{HCO}_{3}^{-}$ & 0.82 \\
\hline Total porosity & 47.20 & $\mathrm{Cl}$ & 99.24 \\
\hline $\mathrm{FC}$ & 25.56 & $\mathrm{SO}_{4}^{2-}$ & 62.80 \\
\hline Bulk density $\left(\mathrm{gcm}^{-3}\right)$ & 1.40 & & \\
\hline Available macronutrients & & $\mathrm{pH}(1: 2.5)$ susp. & 7.65 \\
\hline Available $\mathrm{N} \mathrm{mmol}_{\mathrm{c}} / 100 \mathrm{~g}$ soil & 64.00 & $\mathrm{C} / \mathrm{N}$ ratio & 9.64 \\
\hline Available $\mathrm{P} \mathrm{mmol}_{\mathrm{c}} / 100 \mathrm{~g}$ soil & 10.70 & CEC me/100g soil & 17.40 \\
\hline Available $\mathrm{K} \mathrm{mmol} / 100 \mathrm{~g}$ soil & 315 & & \\
\hline
\end{tabular}

$\mathrm{EC}$ and soluble ions were determined in soil past extract.

\section{RESULTS AND DISCUSSION}

\section{A) Soil salinity:}

Tables (1) and (2) show that total soluble salts percent compost and the soil sample were approximately the same (about $0.5 \%$ ). The behavior of soil salinity through 20 months (the experiment period) was graphically illustrated in Fig. (1). It could be observed that sharp depression was occurred after garlic harvesting. The decrease was gradually. The rate $5 \%$ 
was the fastest in decreasing salinity followed by the rate $2.5 \%$ and unmanured plots were at least. This trend may be attributed to salt recovery by plants enhanced by more water retention due to more compost addition.

From Fig. (1) also, it could be observed that bicarbonates were increased sharply after the early 2 months and still at the same high level for about 3 or 3.5 months and decreased gradually to be after 20 months at a level higher than the start. Those early increases were due to the maximum garlic root activity under relative salinity stress.

Chlorides were sharply reduced after about 2 months and ranged between small differences up to 16 months and tended to little increase after that. Sulphates which were calculated by difference between cations and anions included logically all the other anions as nitrates, phosphates and so on. They reduced gradually at the early 6 months, sharply after another 2 months and still low up to 17 months. A little increase occurred by the experimental end. Applications of 2.5 and $5 \%$ of compost were without real effect in case of bicarbonate but they were more effective in decreasing chlorides and sulphates. In all cases, there was no soluble carbonate. Thus, the soil was not alkali due to $\mathrm{CaCO}_{3}$ buffering capacity.

Soluble cations as Fig. (2) illustrated decreased by time in general. The alkaline or basic cations $\mathrm{Ca}^{2+}$ and $\mathrm{Mg}^{2+}$ were as the same trend as Sulphates while $\mathrm{Na}^{+}$followed the same trend of Chlorides. Regarding the soluble $K$, it reached to soil solution in this experiment from three ways:

1) The native $K$, 2) $K$ released from compost (contained $0.637 \% K$ ) and 3 ) Added mineral $K$ as sulphate or phosphate. Soluble $K$ increased in case of 0 and $2.5 \%$ rate of compost through the early 4 months than the start at 0 times but the rate of $5 \%$ compost decreased it due to more microbiology activity and more $K$ absorption by them. All compost treatments $(0,2.5$ and $5 \%)$ reduced $K$ in soil solution sharply in the next two months and were stable after that till the experiment end. The more compost rate was the more active in reducing $K$ but in narrow differences.

B) Cation exchange capacity (CEC):

Fig. (3) graphically illustrated cation exchange capacity (CEC) behavior which was clearly affected by compost applications where $5 \%$ compst revealed no pronounced change through 20 months while with $5 \%$ compost application and relatively less with $2.5 \%$, CEC increased in the early two months, still high for about 6 months and gradually decreased to near the value with which the experiment started. This could be due to the decomposition of the compost added which is mainly organic matter. It is well known that organic matter has a higher CEC which is reflected on soil CEC.

C) Organic matter content (O.M.):

In Fig. (3) the trend of organic matter content (O.M.) could be described as sharp increasing in $2.5 \%$ and $5 \%$ compost treatments at first two months, as a result of compost addation stability for another four months and gently decreasing. The increases in O.M. were more pronounced at $5 \%$ rate of application than that at $2.5 \%$. That trend was ascribed of course to the quantities added of organic matter to soil and the slow decomposition of that used compost. That result confirmed those obtained by Kaddous and 
Morgans (1986), Kanwar Kamla et al. (2002), Negm et al. (2003) and Khalefa et al (2005).

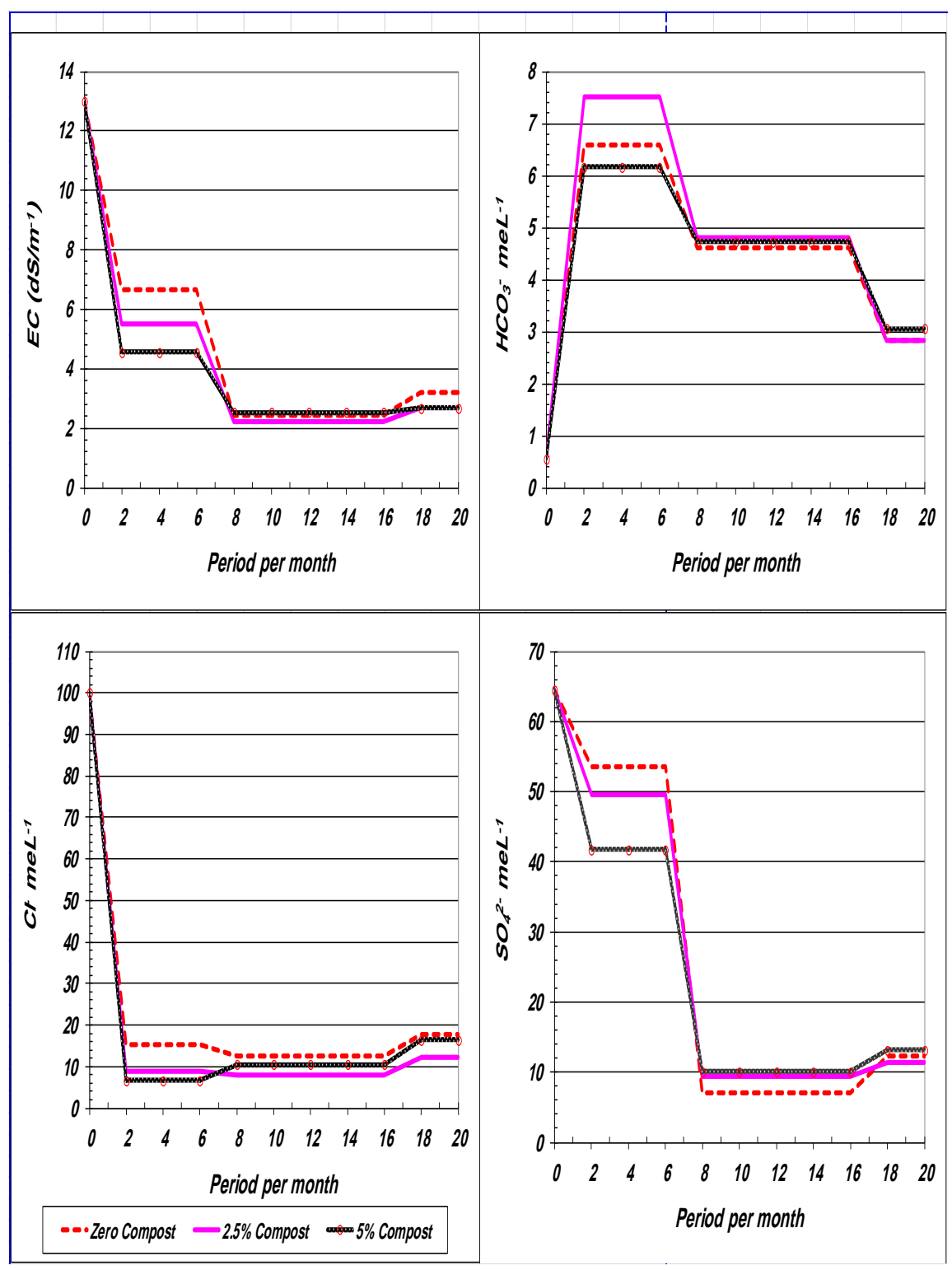

Fig. (1): The behavior of electrical conductivity and soluble anions of saturation paste extract through experiment period. 


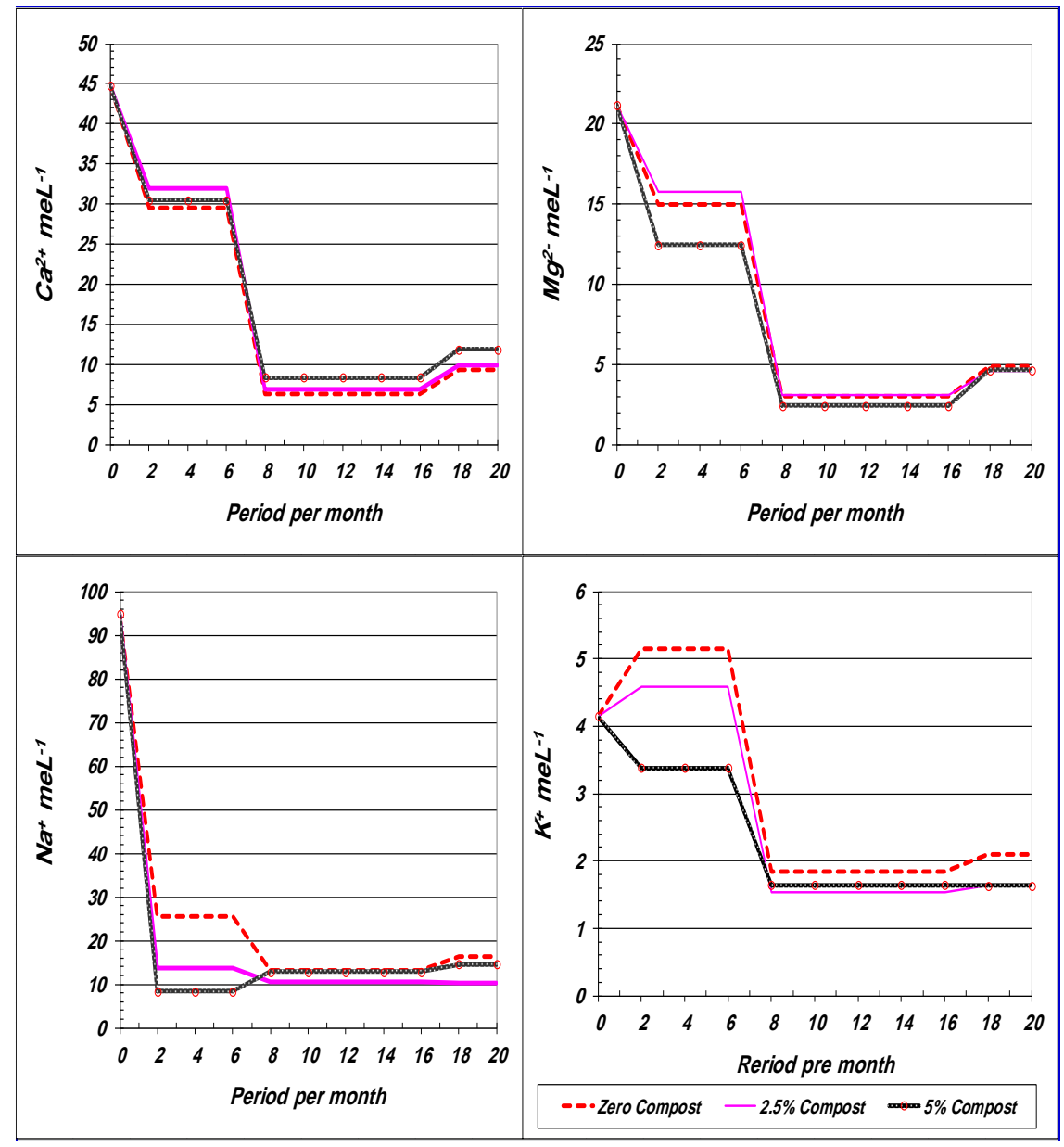

Fig. (2): The behavior of soluble cations of saturation paste extract through experiment period.

\section{D) Total nitrogen content:}

In Fig. (3) also total nitrogen content was illustrated to clarify the continuous decreases in all cases. The dramatic decreases were noticed for control curve followed with that of $2.5 \%$ compost appearing long stable period at $250 \mathrm{mg} / \mathrm{kg}$ soil from the $8^{\text {th }}$ month and up to the $16^{\text {th }}$. That stability by using $5 \%$ compost was between 370 and $390 \mathrm{mg} / \mathrm{kg}$ soil from the $2^{\text {nd }}$ month up to the $16^{\text {th }}$. Total $N$ means all organic, minerals ammoniacal and nitrate $N$ forms. The stability period in presence of plants absorbing nitrogen means regular $\mathrm{N}$ release. Thus, the longer stable $N$ content period is the more regular $N$ released manure. That results were in accordance with those reported by Kaddous and Morgans (1986), Lehmann et al. (2003), Negm et al. (2003) and Khalefa et al (2005). 

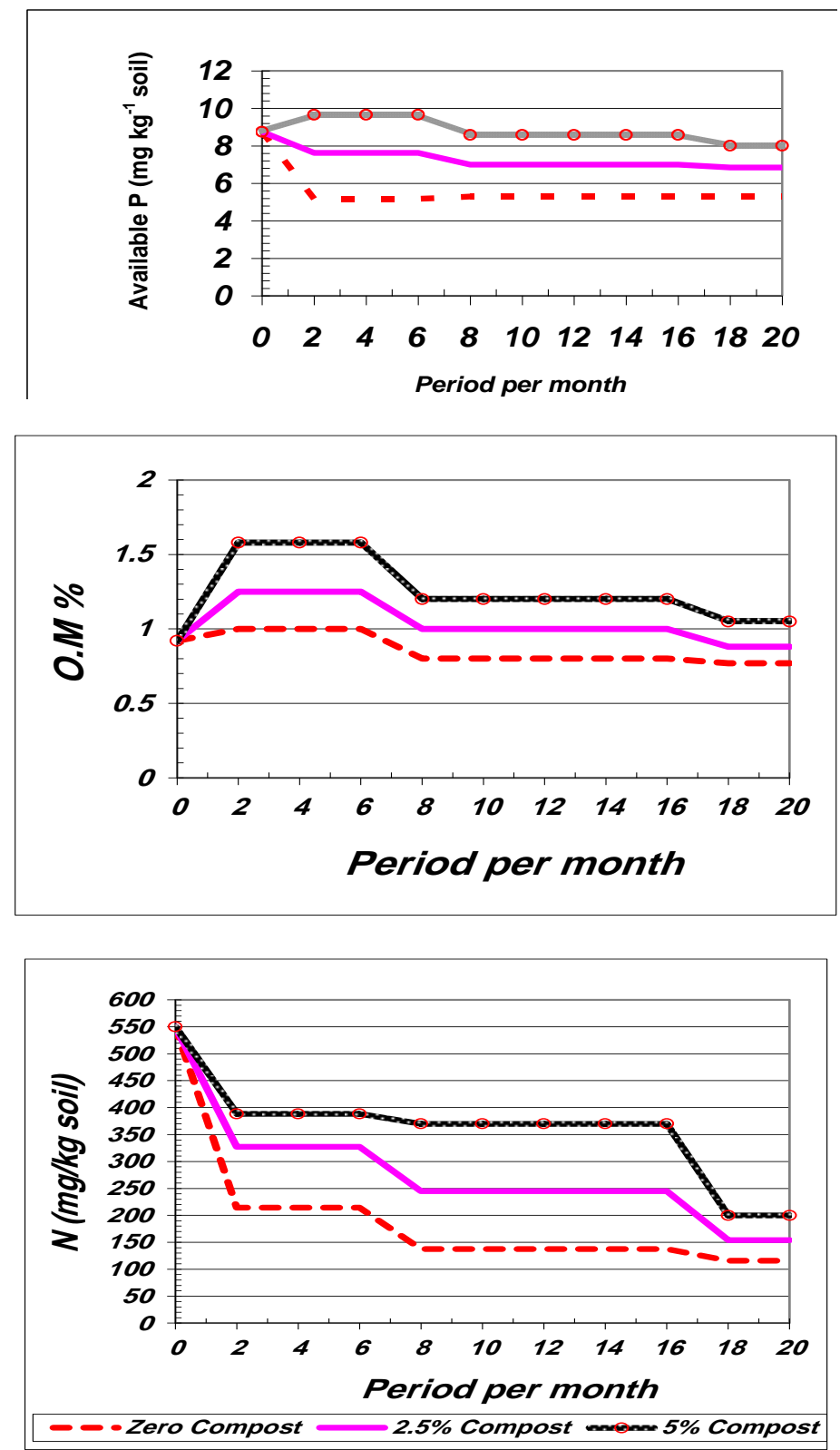

Fig. (3): The behavior of cation exchange capacity, organic matter and total nitrogen in soil due the experiment of period. 


\section{E) Available phosphorus:}

The experiment soil sample was supplied according to the arrangement design with two $P$ sources; organic and mineral. Fig. (4) and Fig (5) illustrated the effect of each source on available $P$.

Concerning plants residues trim farm operations compost, there was proportion increase in available $P$ by increasing the rate of application. The decrease by time was relatively faster in the higher compost rate followed with the low one and the unmanured pots were approximately stable around the lowest available $P$ value during the experimental period lower than the beginning point. This result was in agreement with the findings of Kaddous and Morgans(1986), Lehmann et al. (2003), Negm et al. (2003) and Khalefa et al (2005).

The mineral $P$ applications differed in their effects on available $P$ according to their sources. Additions of diluted $\mathrm{H}_{3} \mathrm{PO}_{4}$ were generally as the same as control with 0.22 or $-0.38 \mathrm{mg} / \mathrm{kg}$ soil more or less, respectively. Monohydrogen dipotassium phosphate application increased available $P$ over the control by using the level corresponding $8 \mathrm{~kg} \mathrm{P/fed}$. The increases were more by using the doubled level. All of them reduced available $P$ by time. As for the effect of $P$ level of application on increasing available $P$, Mengel and Kirkby (1979) and Abd El-Hadi et al (2000) found nearly the same. As for the superiority of potassium phosphate in increasing available $P$ in soil, Mengel and Kirkby (1979), Oosterhuis (1997) and Hamidia et al. (2000) obtained similar results.

\section{F) Available potassium:}

Potassium also was provided by two sources organic and mineral. The mineral was sulphate or phosphate. Its effect on available $K$ was graphically illustrated in Fig. (4) and Fig (5).

Firstly, available $K$ in the soil sample before the experiment was between middle and high limits but under the programme of intensive cultivation, application of $K$ from the studied sources raised available $K$ to the sufficient level through about 16 months and return to the start limit after 20 months when compost was used and less to that limit in unmanured plots.

The high rate of compost increased available $K$ up to 6 months and decreased it gradually to the start point value. Also, the low compost rate raised available $K$ for 6 months and gradually decreased it to a value relatively lower than that of beginning. The control faced at the early 6 months increase in available $K$ due to association of mineral $K$ subtreatments but after 16 months it decreased to the beginning value and lower than that beginning value after 20 months. Results of Kaddous and Morgans (1986), Lehamnn et al. (2003) and Negm et al. (2003) were confirmed with that finding. 

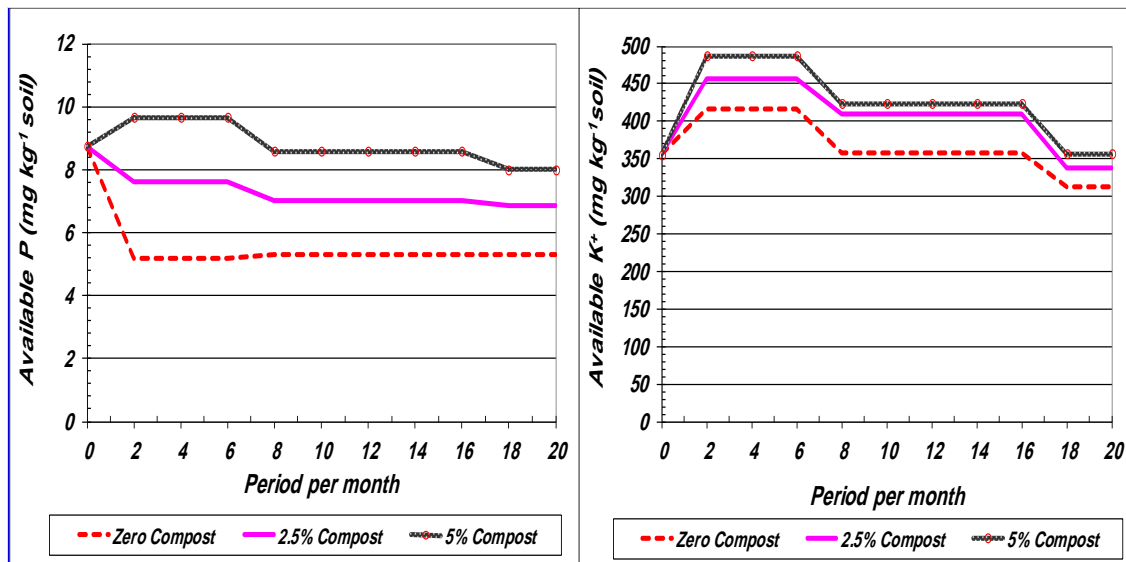

Fig. (4): The behavior of available $P$ and $K$ as affected by compost treatments through the experiment period.

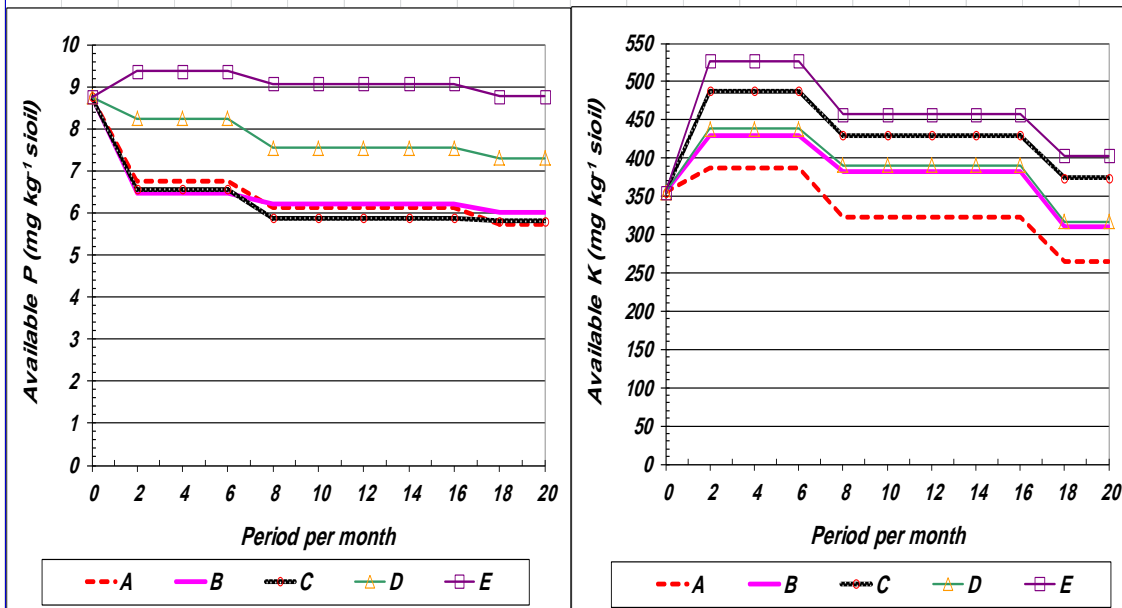

Fig. (5): The behavior of available $P$ and $K$ as affected by potassium sulphate and monohydrogen dipotassium phos treatments through the nexperiment period.

Application of mineral $K$ increased available $K$ over the control (A). The increase of $K$ level of application increased available $K$. That trend was true although the values decreased by time, Mengel and Kirkby (1979) and Abd El_Hadi et al. (2000) obtained similar results.

Among each level, dipotassium phosphate was superior to potassium sulphate in increasing available $K$ in soil through all the experiment intervals. That finding was in agreement with Oosterhuis (1997) and Hamdia et al. (2000).

\section{G) Dry matter yields:}

Data in Table (3) indicated that dry matter yields of the studied vegetable graduated along with compost decomposition as the following.

In garlic, application of $5 \%$ compost reduced significantly dry matter yield than that of 0 or $2.5 \%$ cowpea seeds responded significantly to application of $2.5 \%$ compost while its straw responded significantly to $2.5 \%$ 
and $5 \%$ compost with significant difference between each. Thus, cowpea whole plant increased with 17 and $52 \%$ by addition of 2.5 and $5 \%$ compost over the control indicating that the used plants residues trim farm operations compost start to feed plants after at least the maximum growth period of the $1^{\text {st }}$ crop i.e. after about 2 months of application. The significant superiority of $2.5 \%$ compost to control and that of $5 \%$ to $2.5 \%$ rate of application were shown in dry matter yields with cauliflower, the $3^{\text {rd }}$ crop and jews mallow, the $4^{\text {th }}$ one. These results are in agreements of Kaddous and Morgans (1986) for the negative effect of organic manure at first, Jakse and Mihelic (2001) and Kumar and Chaudhary (2002) for the latter trend.

Using potassium phosphate in both levels was found to be significantly superior to the control in increasing the four crops dry matter yields. Potassium sulphate and phosphoric acid solution in the both levels were also as the same as $\mathrm{HK}_{2} \mathrm{PO}_{4}$ trend for the latter three vegetables and the low level of them was as the same as the control. Thus, the studied calcareous soil was in need to $P$ and $K$ fertilization whatever the added form of each beside released from compost. That finding confirmed with those obtained by Sono et al. (1994), Jana and Mukhopadhyay (2002) for phosphorus and Naik and Hosamani (2003) and Nagoich et al. (2003) for potassium. From other wise dipotassium phosphate caused significant increases over potassium sulphate and phosphoric acid in increasing dry matter yields of cowpea straw, cauliflower and jews mallow by any level of application and the higher $\mathrm{HK}_{2} \mathrm{PO}_{4}$ level over the lower level of $\mathrm{K}_{2} \mathrm{SO}_{4}$ and $\mathrm{H}_{3} \mathrm{PO}_{4}$ in case of garlic and cowpea seed dry matter.

Concerning the interaction effect of compost and $P$ and $K$ mineral fertilization on dry mater yields of that studied vegetables, the highest values were of $\mathrm{HK}_{2} \mathrm{PO}_{4}$ without compost for garlic, $\mathrm{K}_{2} \mathrm{SO}_{4}$ and $\mathrm{H}_{3} \mathrm{PO}_{4}$ or $\mathrm{HK}_{2} \mathrm{PO}_{4}$ with $2.5 \%$ compost for cowpea seeds, $\mathrm{K}_{2} \mathrm{SO}_{4}$ and $\mathrm{H}_{3} \mathrm{PO}_{4}$ with $5 \%$ compost for cowpea straw and $\mathrm{HK}_{2} \mathrm{PO}_{4}$ with $5 \%$ compost for others at level 2 in all cases.

\section{H) Nitrogen uptake:}

From data of Table (4), nitrogen uptake by garlic plants was significantly reduced by compost application especially at the higher rate of application. Referring to the high total nitrogen content in soil at that period. It could attribute that to nitrogen assimilation by microorganisms bodies in the soil or due to decline in available $N$ and not in total $N$ as found by Jakse and Mihelic (2001). That behavior was completely converted to significant effect of $5 \%$ compost over $2.5 \%$ and the latter over unmanured pots on increasing nitrogen uptake by cowpea, cauliflower and jews mallow vegetables. The proportion increases coordinated with Kaddous and Morgans (1986) Khalaf and Taha (1988) and Hanafy et al. (1997).

Phosphorus and potassium applications proportionally increased $N$ uptake by plants with significant differences that their favorite effects on dry matter production caused effect. Generally, the more healthy plants are the more able to absorb nutrients. 


\begin{tabular}{|c|c|c|c|c|c|c|c|c|}
\hline \multirow[t]{3}{*}{ Plant } & \multirow{3}{*}{\begin{tabular}{|l|} 
Compos \\
rate $\%$ \\
\end{tabular}} & \multicolumn{5}{|c|}{ Treatments } & \multirow[t]{3}{*}{ Mean } & \multirow{3}{*}{\begin{tabular}{|c|} 
L.S.D \\
(at 0.05 level) \\
\end{tabular}} \\
\hline & & \multirow{2}{*}{ control } & \multicolumn{2}{|c|}{\begin{tabular}{|l}
$K 2 S O 4$ \\
\end{tabular}} & \multicolumn{2}{|c|}{ HK2PO4 } & & \\
\hline & & & Level 1 & Level 2 & Level 1 & Level 2 & & \\
\hline \multirow{4}{*}{ 忍 } & 0.00 & 16.45 & 16.75 & 21.30 & 26.65 & 30.00 & 22.23 & Compost: 0.28 \\
\hline & 2.50 & 11.40 & 16.35 & 19.95 & 18.25 & 28.30 & 18.85 & Treatmnts: 0.36 \\
\hline & 5.00 & $\begin{array}{l}11.10 \\
1298\end{array}$ & $\frac{12.60}{15.23}$ & $\begin{array}{l}14.75 \\
1867\end{array}$ & $\frac{15.60}{2017}$ & $\frac{17.15}{25.15}$ & 14.24 & Comp. ${ }^{*}$ Treat.: 0.62 \\
\hline & Mean & & & & 20.17 & & 18.44 & \\
\hline \multirow{4}{*}{ 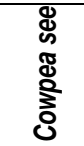 } & 0.00 & 19.55 & 26.30 & 28.65 & 27.75 & 33.85 & 27.22 & Compost: 4.50 \\
\hline & 2.50 & 27.35 & 29.15 & 35.50 & 35.10 & 35.45 & 32.51 & Treatmnts: 5.81 \\
\hline & 5.00 & 25.15 & 30.35 & 29.60 & 34.70 & 35.35 & 31.03 & Comp. ${ }^{*}$ Treat.: 10.06 \\
\hline & Mean & 24.02 & 28.60 & 31.25 & 32.52 & 34.88 & 30.25 & \\
\hline \multirow{4}{*}{ 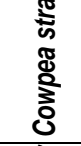 } & 0.00 & 46.20 & 56.55 & 73.85 & 76.80 & 84.05 & 67.49 & Compost: 5.17 \\
\hline & 2.50 & 54.75 & 77.25 & 81.10 & 89.05 & 89.40 & 78.31 & Treatmnts: 6.68 \\
\hline & 5.00 & 86.55 & 111.15 & 125.60 & 119.20 & 120.50 & 112.60 & Comp. ${ }^{*}$ Treat.: 11.57 \\
\hline & Mean & 62.50 & 81.65 & 93.52 & 95.02 & 97.98 & 86.13 & \\
\hline \multirow{4}{*}{ 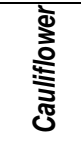 } & 0.00 & 48.25 & 56.00 & 73.65 & 61.00 & 77.55 & 63.29 & Compost: 2.81 \\
\hline & 2.50 & 56.15 & 61.75 & 72.90 & 66.00 & 108.50 & 73.06 & Treatmnts: 3.63 \\
\hline & 5.00 & 75.50 & 99.15 & 110.50 & 105.80 & 114.00 & 100.99 & Comp. ${ }^{*}$ Treat.: 6.29 \\
\hline & Mean & 59.97 & 72.30 & 85.68 & 77.60 & 100.02 & 79.11 & \\
\hline \multirow{3}{*}{ 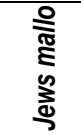 } & 0.00 & 18.75 & 22.47 & 30.40 & 38.25 & 46.27 & 31.23 & Compost: 1.67 \\
\hline & 2.50 & 39.83 & 44.63 & 45.12 & 47.08 & 49.18 & 45.17 & Treatmnts: 2.15 \\
\hline & 5.00 & $\begin{array}{l}40.10 \\
32.89\end{array}$ & $\begin{array}{l}46.18 \\
3776\end{array}$ & 49.02 & 50.75 & 53.20 & $\begin{array}{l}47.85 \\
41.42\end{array}$ & Comp. ${ }^{*}$ Treat.: 4.55 \\
\hline
\end{tabular}

Table (4): Nitrogen uptake by the studied vegetable crops in $\mathrm{mg} / \mathrm{kg}$ soil asaffected by compost and

\begin{tabular}{|c|c|c|c|c|c|c|c|c|}
\hline \multirow[t]{3}{*}{ Plant } & \multirow{3}{*}{\begin{tabular}{|c|} 
Compost \\
rate $\%$ \\
\end{tabular}} & \multicolumn{5}{|c|}{ Treatments } & \multirow[t]{3}{*}{ Mean } & \multirow{3}{*}{$\begin{array}{c}\text { L.S.D } \\
\text { (at } 0.05 \text { level) }\end{array}$} \\
\hline & & \multirow{2}{*}{ control } & \multicolumn{2}{|c|}{$\mathrm{K}_{2} \mathrm{SO}_{4}$} & \multicolumn{2}{|c|}{$\mathrm{HK}_{2} \mathrm{PO}_{4}$} & & \\
\hline & & & Level 1 & Level 2 & Level 1 & Level 2 & & \\
\hline \multirow{4}{*}{ 产 } & 0.00 & 276.25 & 311.55 & 447.25 & 527.65 & 698.90 & 452.32 & Compost: 4.09 \\
\hline & 2.50 & 173.25 & 279.55 & 384.90 & 333.95 & 594.30 & 353.19 & Treatmnts: 5.28 \\
\hline & 5.00 & 155.40 & 204.35 & 271.30 & 271.40 & 333.90 & 247.27 & Comp.* Treat.: 9.14 \\
\hline & Mean & 201.63 & 265.15 & 367.82 & 377.67 & 542.37 & 350.93 & \\
\hline \multirow{4}{*}{ 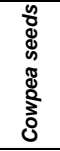 } & 0.00 & 375.50 & 643.10 & 757.85 & 659.55 & 843.55 & 655.91 & Compost: 72.92 \\
\hline & 2.50 & 703.30 & 834.85 & 1169.95 & 961.75 & 1084.75 & 950.92 & Treatmnts: 94.14 \\
\hline & 5.00 & 708.55 & 1007.00 & 1237.10 & 1086.95 & 1273.00 & 1062.52 & Comp. ${ }^{\star}$ Treat.: 163.06 \\
\hline & Mean & 595.78 & 828.32 & 1054.97 & 902.75 & 1067.10 & 889.78 & \\
\hline \multirow{4}{*}{ 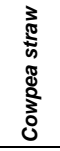 } & 0.00 & 999.80 & 1144.15 & 1470.00 & 1567.15 & 1686.65 & 1373.55 & Compost: 68.31 \\
\hline & 2.50 & 1083.40 & 1402.95 & 1579.95 & 1664.30 & 1676.30 & 1481.38 & Treatmnts: 88.19 \\
\hline & 5.00 & 1393.15 & 1767.35 & 1904.45 & 2022.80 & 2023.55 & 1822.26 & Comp. ${ }^{*}$ Treat.: 152.74 \\
\hline & Mean & 1158.78 & 1438.15 & 1651.47 & 1751.42 & 1795.50 & 1559.06 & \\
\hline \multirow{4}{*}{ 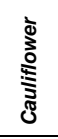 } & 0.00 & 534.70 & 620.55 & 883.15 & 670.40 & 922.25 & 726.21 & Compost: $\mathbf{3 1 . 4 3}$ \\
\hline & 2.50 & 707.05 & 869.60 & 1083.50 & 890.30 & 1506.70 & 1011.43 & Treatmnts: $\mathbf{4 0 . 5 8}$ \\
\hline & 5.00 & 1049.20 & 1476.05 & 1789.35 & 1551.00 & 1766.15 & 1526.35 & Comp. ${ }^{*}$ Treat.: 70.29 \\
\hline & Mean & 763.65 & 988.73 & 1252.00 & 1037.23 & 1398.37 & 1088.00 & \\
\hline \multirow{4}{*}{ 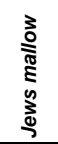 } & 0.00 & 378.75 & 467.30 & 710.75 & 822.40 & 1115.05 & 698.85 & Compost: 6.63 \\
\hline & 2.50 & 868.35 & 941.75 & 974.50 & 943.75 & 1175.50 & 980.77 & Treatmnts: 8.55 \\
\hline & 5.00 & 785.95 & 1020.65 & 1147.00 & 1060.65 & 1212.95 & 1045.44 & Comp. ${ }^{*}$ Treat.: 14.82 \\
\hline & Mean & 677.68 & 809.90 & 944.08 & 942.27 & 1167.83 & 908.35 & \\
\hline \multirow{4}{*}{$\frac{\frac{0}{\frac{5}{\pi}}}{\frac{5}{5}}$} & 0 & 2565.00 & 3186.65 & 4269.00 & 4247.15 & 5266.40 & 3906.84 & Compost: 21.07 \\
\hline & 2.5 & 3535.35 & 4328.70 & 5192.80 & 4794.05 & 6037.55 & 4777.69 & Treatmnts: $\mathbf{2 7 . 2 0}$ \\
\hline & 5 & 4092.25 & 5475.40 & 6349.20 & 5992.80 & 6609.55 & 5703.84 & Comp.* Treat.: 47.11 \\
\hline & Mean & 3397.53 & 4330.25 & 5270.33 & 5011.33 & 5971.17 & 4796.12 & \\
\hline
\end{tabular}


That result was in agreement with Jana and Mukhopadhyay (2002) for phosphorus, Naidu et al. (2000) and Nagoich et al. (2003) for potassium and Naik and Hosamani (2003) for phosphorus and potassium.

Among each level of $P$ and $K$ potassium phosphate was significantly superior in increasing $N$ uptake by cowpea straw, cauliflower and Jews mallow to $\mathrm{K}_{2} \mathrm{SO}_{4}$ and $\mathrm{H}_{3} \mathrm{PO}_{4}$.

Total nitrogen uptake followed the current trends of its components giving compost efficiency about 82 and $85.5 \%$ for the application rates of 2.5 and $5.0 \%$ respectively on the lassies that each plot of the lower compost rate contained $375 \mathrm{~g} \mathrm{~N}$ from compost and $750 \mathrm{~g} \mathrm{~N}$ from the higher rate excluding nitrogen taken up by plants of no compost.

I) Phosphorus uptake:

Table (5) revealed that phosphorus uptake by plants was also significantly affected by compost application as the following.

\begin{tabular}{|c|c|c|c|c|c|c|c|c|}
\hline \multirow[t]{3}{*}{ Plant } & \multirow{3}{*}{$\begin{array}{c}\text { Compost } \\
\text { rate } \% \\
\end{array}$} & \multicolumn{5}{|c|}{ Treatments } & \multirow[t]{3}{*}{ Mean } & \multirow{3}{*}{$\begin{array}{c}\text { L.S.D } \\
\text { (at } 0.05 \text { level) }\end{array}$} \\
\hline & & \multirow{2}{*}{ control } & \multicolumn{2}{|c|}{$\mathrm{K}_{2} \mathrm{SO}_{4}$} & \multicolumn{2}{|c|}{$\mathrm{HK}_{2} \mathrm{PO}_{4}$} & & \\
\hline & & & Level 1 & Level 2 & Level 1 & Level 2 & & \\
\hline \multirow{4}{*}{ : } & 0.00 & 31.20 & 38.50 & 53.20 & 55.95 & 92.95 & 54.36 & Compost: 1.04 \\
\hline & 2.50 & 23.95 & 34.30 & 59.80 & 62.05 & 96.20 & 55.26 & Treatmnts: 1.35 \\
\hline & 5.00 & 27.75 & 41.60 & 54.55 & 59.25 & 71.60 & 50.95 & Comp. * Treat.: 2.33 \\
\hline & Mean & 27.63 & 38.13 & 55.85 & 59.08 & 86.92 & 53.52 & \\
\hline \multirow{4}{*}{ 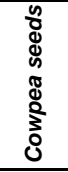 } & 0.00 & 30.35 & 62.90 & 68.65 & 74.90 & 101.50 & 67.66 & Compost: 3.74 \\
\hline & 2.50 & 57.05 & 69.50 & 88.45 & 94.75 & 113.45 & 84.64 & Treatmnts: 4.83 \\
\hline & 5.00 & 56.85 & 70.70 & 83.35 & 99.95 & 115.70 & 85.31 & Comp. * Treat.: 8.36 \\
\hline & Mean & 48.08 & 67.70 & 80.15 & 89.87 & 110.22 & 79.20 & \\
\hline \multirow{4}{*}{ 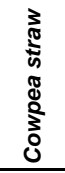 } & 0.00 & 87.55 & 141.15 & 205.75 & 214.10 & 234.65 & 176.64 & Compost: 3.28 \\
\hline & 2.50 & 130.90 & 191.40 & 208.10 & 265.30 & 277.50 & 214.64 & Treatmnts: 4.23 \\
\hline & 5.00 & 241.40 & 365.75 & 413.65 & 356.15 & 468.35 & 369.06 & Comp. ${ }^{*}$ Treat.: 7.33 \\
\hline & Mean & 153.28 & 232.77 & 275.83 & 278.52 & 326.83 & 253.45 & \\
\hline \multirow{4}{*}{ 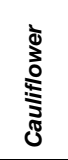 } & 0.00 & 71.90 & 88.90 & 117.55 & 103.20 & 154.90 & 107.29 & Compost: 5.05 \\
\hline & 2.50 & 100.95 & 116.85 & 151.95 & 144.85 & 248.45 & 152.61 & Treatmnts: 6.25 \\
\hline & 5.00 & 150.65 & 197.90 & 220.50 & 221.55 & 261.80 & 210.48 & Comp. ${ }^{*}$ Treat.: 11.29 \\
\hline & Mean & 107.83 & 134.55 & 163.33 & 156.53 & 221.72 & 156.79 & \\
\hline \multirow{8}{*}{ 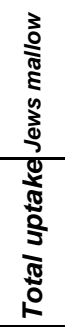 } & 0.00 & 28.15 & 31.45 & 42.55 & 53.55 & 69.40 & 45.02 & Compost: 0.46 \\
\hline & 2.50 & 59.75 & 66.95 & 63.15 & 67.40 & 68.85 & 65.22 & Treatmnts: 0.59 \\
\hline & 5.00 & 64.15 & 69.30 & 73.55 & 71.05 & 85.10 & 72.63 & Comp. ${ }^{*}$ Treat.: 1.03 \\
\hline & Mean & 50.68 & 55.90 & 59.75 & 64.00 & 74.45 & 60.96 & \\
\hline & 0.00 & 249.15 & 362.90 & 487.70 & 501.70 & 653.40 & 450.97 & Compost: 70.24 \\
\hline & 2.50 & 372.60 & 479.00 & 571.45 & 634.35 & 804.45 & 572.37 & Treatmnts: 90.68 \\
\hline & 5.00 & 540.80 & 745.25 & 845.60 & 807.95 & 1002.55 & 788.43 & Comp. ${ }^{*}$ Treat.: 157.06 \\
\hline & Mean & 387.52 & 529.05 & 634.92 & 648.00 & 820.13 & 603.92 & \\
\hline
\end{tabular}

Compost in the early months of decomposition produced garlic week plants especially at $5 \%$ rate of application. These plants were low in their $P$ 
uptake, which were significantly decreased than total of 2.5 and the control treatments. After that compost proportionally increased $\boldsymbol{P}$ uptake by the other vegetables. The difference between $5 \%$ and $2.5 \%$ as well as between $2.5 \%$ and the control were significant with one exception that between 5 and $2.5 \%$ which was insignificantly in case of cowpea seeds. The good supplying compost with $P$ was in agreement with Kaddous and Morgans (1986), Khalaf and Taha (1988) and Lehmann et al. (2003).

Regarding $P$ uptake by plants as affected by mineral $P$ sources, it could be noticed that all the studied vegetable responded to the mineral $P$ fertilization significantly. The high level of application was the more effective among each from $\left(\mathrm{H}_{3} \mathrm{PO}_{4}\right.$ or $\left.\mathrm{HK}_{2} \mathrm{PO}_{4}\right)$ with significant differences. Naidu et al. (2000) Jana and Muklopadhyay (2002) and Naik and Hosamani (2003) obtained similar results. The comparison between mineral $P$ sources indicated the dipotassium phosphate was significantly superior to diluted H3PO4 in increasing P uptake by any of the studied vegetables among each level of application.

Interaction effect of compost and mineral $\mathrm{P}$ fertilization revealed that combination of $2.5 \%$ compost and HK2PO4 in garlic and combination of $5 \%$ compost and $\mathrm{HK}_{2} \mathrm{PO}_{4}$ in the following crops each at the higher level of $\mathrm{HK}_{2} \mathrm{PO}_{4}$.

\section{J) Potassium uptake:}

Table (6) clarified values of $K$ uptake by different vegetables. Compost reduced $K$ taken up by garlic significantly due to previously explanation The proportion increases by increasing rate of compost application were pronounced in all the other vegetables above significance level. That results were in accordance with Kaddous and Morgans (1986), Khalaf and Taha (1988) and Lehmann et at. (2003).

Although $K$ uptake by jews mallow as affected by compost and / or $P$ and $K$ applications followed the same trend of that resulted in case of cowpea and cauliflower, the differences between treatments were insignificant. That observation indicated that storage of $K$ from compost added to the beginning of the experiment of mineral $K$ added to cauliflower, the pervious crop, was less to give Jew's mallow the significant high supply over the untreated plots. Potassium fertilization caused significant magnitude of $K$ uptake by the all studied crops and raising its level of application raised the $K$ amount taken up significantly. Naidu et al. (2000) and Nagoich et al. (2003) obtained nearly similar trends 
Hassanein, A. H. A et al.

Table (6): Potassium uptake by the studied vegetable crops in $\mathrm{mg} / \mathrm{kg}$ soil as affected by compost

\begin{tabular}{|c|c|c|c|c|c|c|c|c|}
\hline \multirow[t]{3}{*}{ Plant } & \multirow{3}{*}{$\begin{array}{c}\text { Compost } \\
\text { rate \% } \\
\end{array}$} & \multicolumn{5}{|c|}{ Treatments } & \multirow[t]{3}{*}{ Mean } & \multirow{3}{*}{$\begin{array}{c}\text { L.S.D } \\
\text { (at } 0.05 \text { level) } \\
\end{array}$} \\
\hline & & \multirow{2}{*}{$\cos ^{\operatorname{ntr}^{\mathrm{d}} \mathrm{l}}$} & \multicolumn{2}{|c|}{$\mathrm{K}_{2} \mathrm{SO}_{4}$} & \multicolumn{2}{|c|}{$\mathrm{HK}_{2} \mathrm{PO}_{4}$} & & \\
\hline & & & Level 1 & Level 2 & Level 1 & Level 2 & & \\
\hline \multirow{4}{*}{ ָู } & 0.00 & 189.05 & 219.40 & 296.05 & 251.70 & 401.90 & 271.62 & Compost: 2.16 \\
\hline & 2.50 & 137.95 & 206.00 & 275.25 & 231.75 & 400.45 & 250.28 & Treatmnts: 2.78 \\
\hline & 5.00 & 139.90 & 163.80 & 212.40 & 213.70 & 246.90 & 195.34 & Comp.* Treat.: 4.82 \\
\hline & Mean & 155.63 & 196.40 & 261.23 & 232.38 & 349.75 & 239.08 & \\
\hline \multirow{4}{*}{ 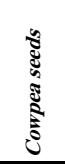 } & 0.00 & 328.15 & 461.90 & 544.10 & 510.55 & 649.95 & 498.93 & Compost: 40.90 \\
\hline & 2.50 & 479.40 & 528.60 & 675.10 & 656.35 & 733.80 & 614.65 & Treatmnts: 52.81 \\
\hline & 5.00 & 481.20 & 609.30 & 675.20 & 673.95 & 751.30 & 638.19 & Comp.* Treat.: 91.46 \\
\hline & Mean & 429.58 & 533.27 & 631.47 & 613.62 & 711.68 & 583.92 & \\
\hline \multirow{4}{*}{ 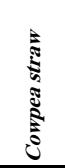 } & 0.00 & 566.80 & 717.95 & 1014.30 & 1053.15 & 918.15 & 854.07 & Compost: 56.25 \\
\hline & 2.50 & 687.25 & 1006.30 & 1052.35 & 1212.75 & 1324.00 & 1056.53 & Treatmnts: 72.62 \\
\hline & 5.00 & 1237.05 & 1620.45 & 1961.10 & 1679.00 & 1828.75 & 1665.27 & Comp.* Treat.: 125.78 \\
\hline & Mean & 830.37 & 1114.90 & 1342.58 & 1314.97 & 1356.97 & 1191.96 & \\
\hline \multirow{4}{*}{ 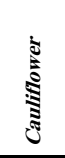 } & 0.00 & 698.25 & 888.70 & 1262.50 & 981.15 & 1364.60 & 1039.04 & Compost: 34.32 \\
\hline & 2.50 & 925.80 & 1078.45 & 1403.40 & 1193.25 & 2123.65 & 1344.91 & Treatmnts: 44.30 \\
\hline & 5.00 & 1366.30 & 1862.15 & 2286.45 & 2040.50 & 2404.55 & 1991.99 & Comp.* Treat.: 76.73 \\
\hline & Mean & 996.78 & 1276.43 & 1650.78 & 1404.97 & 1964.27 & 1458.65 & \\
\hline \multirow{4}{*}{ 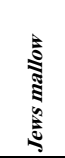 } & 0.00 & 585.00 & 700.95 & 1138.80 & 1193.40 & 1841.40 & 1091.91 & Compost: N.S* \\
\hline & 2.50 & 1171.10 & 1312.20 & 1339.95 & 1415.60 & 1460.75 & 1339.92 & Treatmnts: N.S \\
\hline & 5.00 & 1182.95 & 1326.45 & 1455.80 & 1507.25 & 1771.55 & 1448.80 & Comp.* Treat.: N.S \\
\hline & Mean & 979.68 & 1113.20 & 1311.52 & 1372.08 & 1691.23 & 1293.54 & \\
\hline \multirow{4}{*}{ ปี } & 0.00 & 2367.25 & 2988.90 & 4255.75 & 3989.95 & 5176.00 & 3755.57 & Compost: 78.46 \\
\hline & 2.50 & 3401.50 & 4131.55 & 4746.05 & 4709.70 & 6042.65 & 4606.29 & Treatmnts: 101.29 \\
\hline & 5.00 & 4407.40 & 5582.15 & 6590.95 & 6114.40 & 7003.05 & 5939.59 & Comp.* Treat.: 175.44 \\
\hline & Mean & 3392.05 & 4234.20 & 5197.58 & 4938.02 & 6073.90 & 4767.15 & \\
\hline
\end{tabular}

${ }^{\star} \mathrm{N} . \mathrm{S}=$ Not significant

The mineral $K$ sources were also with significant effect on $K$ uptake where dipotassium phosphate was superior to potassium sulphate for all the studied plants among each level of application.

Combination of the higher levels of compost and $\mathrm{HK}_{2} \mathrm{PO}_{4}$ produced the highest $K$ uptake value by cowpea; cauliflower and jews mallow while the higher level of $\mathrm{HK}_{2} \mathrm{PO}_{4}$ with or without $2.5 \%$ to compost was the best treatment in case of garlic.

So it can be concluded that the rates of applying compost with levels of phosphorus and potassium improve the properties of calcareous soil and provide nutrients phosphorus and potassium for four seasons for vegetable crops, and increase crop production vegetable in calcareous soils due to the direct impact and resdual to fertilize organic and mineral nitrogen and phosphorus during the 20 month and fertilization potassium through threequarters of that period. 


\section{REFERENCES}

Abd El-Hadi, A.H., R. Abou El-Enein, A.Y. Negm and M. Jacob (2000). Sustainability of soil fertility status after 3 year crop rotation at Middle Egypt Region. th International Colloquium for the Optimization of Plant Nutrition, April 8-13, 2000, Cairo, Egypt, (section 16).

Black, C.A. (ed.), D.D. Evans, F.E. Ensminger, J.I. White, F.E. Clarck and R.C. Dinaver (1965). Methods of Soil I and II Analysis. Ser. Agron No 9 Am. Soc. Agron., Madison, Wisconsim.

Bertrant Kehres and Andreas (1994). Methods Book for Analysis of compost publisher federal compost quality. Assuran Organization (FCQAO).

Brummer, P.H. and H.R. Wasmer (1978). Methods of Analysis of Sewage Sludge, Solid Wasta and Compost. WHO International Reference Center for Waste Disposal Ch 8600 Dubendorf , Suitzerland.

Chapman, H.D. and P.F Pratt (1961). Methods of Analysis for Soil, plant and Waters. Univ. Calif. Devision of Agric. Sci.

Gupta, A.K., J. Kumar and P.S. Arya (2002). Influence of nitrogen, boran and transplanting dates on dry matter accumulation and uptake of nutrients in cauliflower (Brassica oleracea var botrytis L. ) Haryana J. Hort. Sci., $31(3 / 4)$ 283-285.

Jackson, M.L. (1973). Soil Chemical Analysis. Prentice Hall of India Private Limited, New Delhi, India.

Jackson, M.L. (1973). Soil Chemical Analysis. Prentice Hall of India Private Limited, New Delhi, India.

Hanafy, A., A.H., N.F. Kheir and N.B. Talaat (1997). Phsiolological studies on reducing the accumulation of nitrate in Jew's mallow and Radish. Bull. Fac. Agric . Univ. Cairo, 48:25-64.

Hamdia, M.A., H.M.A.El-Komy and N.Barakat (2000). The role of foliar phosphorus and potassium fertilization and / or Azospirillium lipoforum or Bacillus polymex. Inoculation in Nitrogen fixation $\left({ }^{15} \mathrm{~N}\right)$ and mineral of maize grown under salt stress. th International Colloquium for the Optimization of Plant Nutrition,April 8-13,2000,Cairo,Egypt,(section 16).

Jakse, M. and R. Mihelic (2001). Comparison of fertilization with organic or mineral fertilizers in a three year vegetable crop rotation. Zbor Biotehmiske Fakultete Univerze Ljulblj ani Kmetij tvo, 77 (2) : 179-190. (c.f. Hort . Alss 72 (7) [ 6432].

Jana, J.C and T.P. Mukhopadhyay (2002). Effect of nitrogen and phosphorus no seed production of cauliflower var. Aghani in teria zone of West Bengal. Seed Research , 30 (2) : $253-257$.

Jim, Yan, L. Yamxia, Chen TongBin and Lu Shuqin (2002). Effects of sewage sludge compost and heavy metal accumulation in them, Plant Nutrition \& Fert . Sci., 8 (3) : 288-291.

Kaddous, F.G.A. and A.S Morgans (1986). Spent mushroom compost and deep litter fowl manure as a soil ameliorant for vegetables. Surface management Proc., New Zealand Soc. Of Soil Sci-Australian Soc. Of Soil Sci. Inc. Joint conference. November 1986: 138-147. 
Kanwar, Kamla, S.S. Paliyai and T.R. Nandal (2002). Integrated nutrient management in cauliflower (Pusa S now Ball K-1, Research on Crops, 3 (3): 579-583.

Khalaf, S.M. and E.M. Taha (1988). Response of garlic plants grown on calcareous soil to organic mamuring and sulphur application. A nmals of Agric. Sci., Cairo, 33 (2) : 1219-1232. But if

Kumar, S., and D.R.Choudhary (2002). Effect of FYM, molybdenum and boron application on yield attributes and yield of cauliflower. Crop Research, 24 (3) 494 - 496.

Lehmann, J., J.P.de Silva Junior, C. Steiner, S.T. Nehi, W. Zech and B. glaser (2003). Nutrient availability and leaching in an archaeological Authrosol and a Fersalsol of the central Amason basin : fertilizer, manure and charcoal amendments. Plantes Soil , 249 (2) : $343-357$.

Mengel, K. and E.A.Kirkby (1979). Principles of Plant Nutrition. Ber Bund A.G., Bern, Suitzerland.

Mishra, H.P. (1992). Effect of Nitrogen, its time of application and born on cauliflower seed production in calcareous soil Indian J. Hort., 49 (1) : 83-86.

Mohamed, M.J. and Zuraiqi, Said (2003). Enhancement of yield and nitrogen and water use efficiencies by nitrogen drip- fertigation of garlic. J. Plant Nutrition , 26 (9) : $1749-1766$.

Nagoich, K.N., S.K. Trvedi and Rajesh Lekhi (2003). Effect of suplhur and potash on growth, yield and quality of garlic (Allium Sativum limm). Scientific Hort, 8 : 143-147.

Naidu, A.K., J.p Tiwari, S.K. Dvidiedi and S.K. Saxena (2000). Effect of various levels of $N, P, K$ and physiological growth determination of productivity in garlic ( Alliumsativum Linn). Vegetables Sci., 27 (2) : 165-167.

Naik , B.H. and R.M. Hosamani (2003). Standardization of fertilization of garlic production under transitional tract of Karmotako. Karmataka J. Agric . Sci., 16(1) : $103-107$.

Negm, M.A. M.G.M.Rifaat and A.N.Estefanous (2003). Impact of compost saw-dust and some nitrogenous sources on the production of squash and table beet crops grown on a calcareous soil. Fayoum J. Agric. Res.\& Dev., 17 (1): $116-137$.

Oosterhuis, D.M. (1997). Foliar fertilization of cotton with potassium. Proceeding FAO - IRCRNC Joint Meeting Working Groups $20-23$ March 1995, Cairo. Egypt.

Oliveria, A.P., V.R. E.de Silva, F.P.de Arruda , I.S. Nascimento and A.U. de Alves (2003). Yeild of cowpea . beans as a result of levels of doses and ways of application of nitrogen. Hort. Brasileria , 21 (1) : 77-80.

Patidar, M., Anurag Saxena and S.R. Siyak (2003). Effect of Nitrogen fertilization on fodder cowpea (Vigna unguiculata $L$ ) v2 Walp grown in association with Khejri in arid zone. Forage Research , 28 (4) : 201 203. 
Petersen, R.G. (1976). Experimental Design for Agricultural tural Research in Developing Areas. O.S.U Book Stores Inc. Corvallia. Oregon, Litho, U.S.A.

Reeh, II and M.B. Jensen (2002). Yield and quality of leek in response to compost applied as a mulch or incorporated into the soil. Compost Sci. \& tilization $10(3): 244-248$.

Rubatzky, V.E. and M. Yamagucbi (1999). World Vegetables; Principles, Production and Nutritive Values. An Aspen Publication. Aspen publishers Inc. Gaithersburg, Maryland.

Selvi, D., P. Santly and M. Dhakshimamoorthy (2002). Effect of continuous applications of organic and inorganic fertilizers on micronutrient status of an in ceptisol. Agropedology , 12 (2): 148-156.

Sommers, L.E. and D.W. Nelson (1972). Determination of total phosphorus in soil. A rapid perochloric acid digestion producedure. Soil Sci. Soc. Amer. Proc. 36 : 902 - 904.

Sono, S.G. G Saliba., F.J. de Paula , P.S.Koga (1994). Effects phosphate and earthworm compost on garlic (Allium satiuvm L ) cv Roxo Perola de Cacador. Culture Agronomica, 3 (1) : 27-31.

Tindall, H.D. (1983). Vegetables in the Tropics. Macmillan Press. London. 
تأثير الكمبوست وفوسفات البوتاسيوم المضساف لأرض جيريـة منزرعـه بمحاصيل

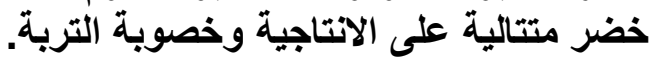

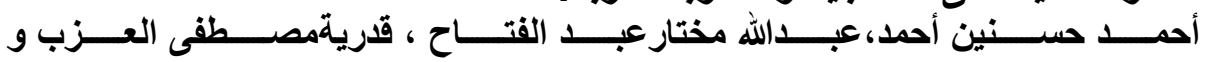
احمد حمادة عبد الرحمن إندا معهد بحوث الأراضى والمياة والبيئة ـ مركز البحوث الزراعية ـ الجيزة ـ مصر.

إجريت تجربة حقلية فى أرض جيرية بقرية أبو مسعود جنوب الاسكندرية ب 48 كم زرعت بـون بأربعة

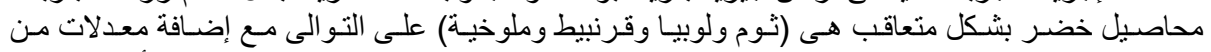

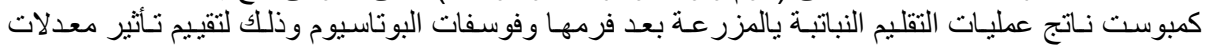

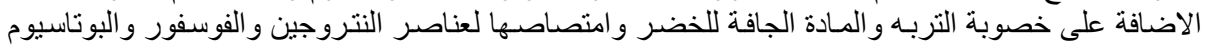

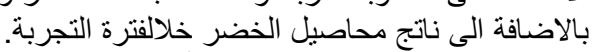

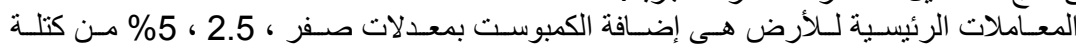

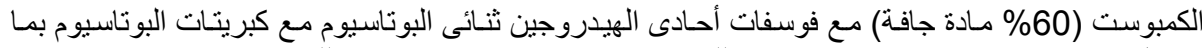

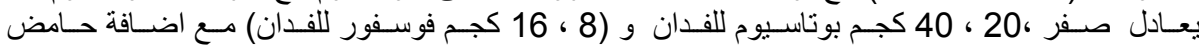

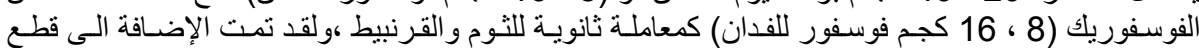

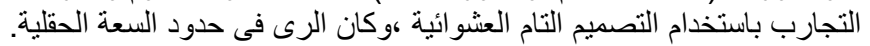
وقد أوضحت النتائج الأتى:

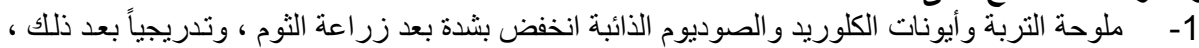

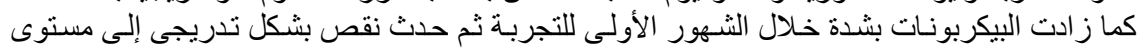

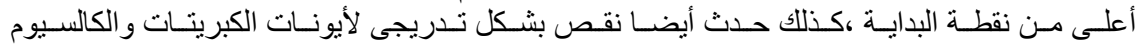

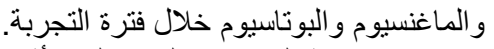

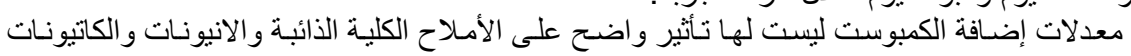

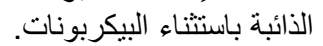

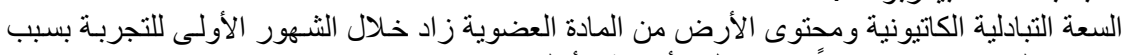

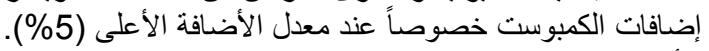

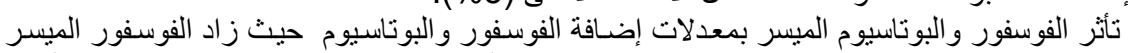

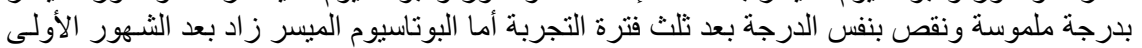

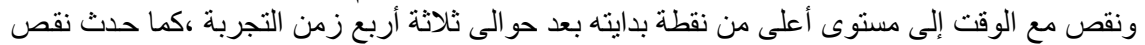

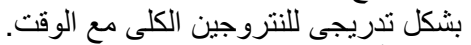

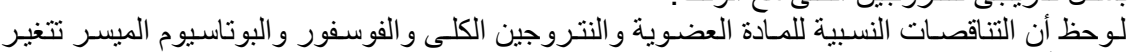

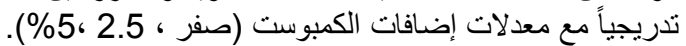

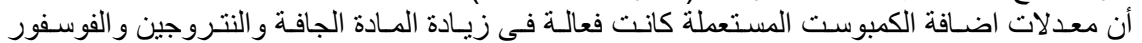

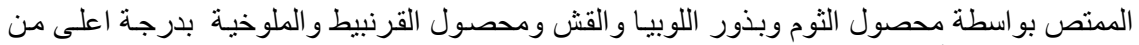

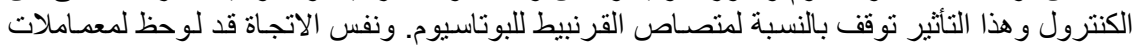

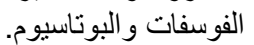

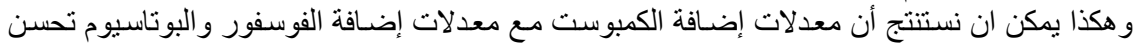

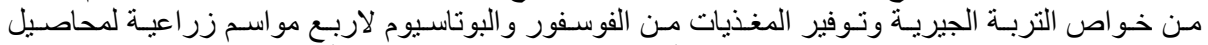

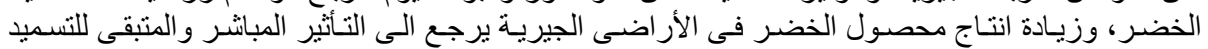

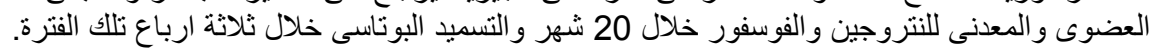


J. Soil Sci. and Agric. Eng., Mansoura Univ., Vol. 5 (7), July, 2014 